2008

\title{
An Environmental Justice Analysis: Superfund Sites and Surrounding Communities in Illinois
}

Angela Maranville

West Virginia University, angela.maranville@mail.wvu.edu

Tih-Fen Ting

University of Illinois at Springfield, tting1@uis.edu

Yang Zhang

Virginia Polytechnic Institute and State University, yz@vt.edu

Follow this and additional works at: https://researchrepository.wvu.edu/faculty_publications

Part of the Environmental Health and Protection Commons, Environmental Indicators and Impact Assessment Commons, Environmental Studies Commons, and the Urban Studies and Planning Commons

\section{Digital Commons Citation}

Maranville, Angela; Ting, Tih-Fen; and Zhang, Yang, "An Environmental Justice Analysis: Superfund Sites and Surrounding Communities in Illinois" (2008). Faculty Scholarship. 439.

https://researchrepository.wvu.edu/faculty_publications/439 
AN ENVIRONMENTAL JUSTICE ANALYSIS:

SUPERFUND SITES AND SURROUNDING COMMUNITIES IN ILLINOIS

\author{
Angela Maranville \\ Tih-Fen Ting \\ Yang Zhang \\ Department of Environmental Studies \\ University of Illinois at Springfield \\ One University Plaza, PAC 308 \\ Springfield IL 62704
}

May 31, 2008

Correspondence: Angela Maranville, amara2@uis.edu. 


\section{Abstract}

Is there an association between Superfund sites and the socioeconomic makeup of the surrounding communities? This research analyzes the current economic and racial demographics of Illinois counties that contain Superfund sites. Specifically, variables that are indicators of environmental injustice are analyzed; e.g. race, median household income, and home ownership. Since the inception of the environmental justice movement in the late 1980s, studies have been conducted nationally and at state levels in Michigan, California, Ohio, Florida, Texas, and South Carolina (i.e. Cutter 2006; Mohai \& Saha 2006; Pastor et al. 2004; Anderton et al. 1997; Bevc et al. 2007; Bowen et al. 1995). However, environmental justice research specific to the state of Illinois is largely unexplored. This research will better identify environmental disparities in rural Illinois counties that have little or no minority population. Additionally, this research adopts a distance-based spatial analysis approach in an attempt to achieve results more precise than previous unit-hazard coincidence analysis methods (Mohai \& Saha 2006).

Areal apportionment methodology is used to analyze demographic data from the 2000 United States (U.S.) Census Summary Files (SF1 and SF3) for the impacted counties in Illinois. This research uses ArcView GISTM (Version 9.2) to create buffer zones of one-, two-, and fivemiles centered on X, Y coordinates obtained from the U.S. Environmental Protection Agency. These uniform neighborhoods are used to determine percentages of racial minority, median household income, and home ownership within these radii. The results are then compared to percentages calculated from the remainder of the county population to establish foremost, if specific environmental injustice criteria are met and subsequently, examine how social and racial demographics within the buffer zone vary with respect to the distance from the Superfund site. 
This research yields essential data for urban and community planners within Illinois. First, this research identifies areas of environmental inequality to be targeted for future amelioration. Secondly, this research better characterizes the relationship between environmental hazards and surrounding communities, both urban and rural. Thirdly, this research will enable city planners to site future environmental hazards judiciously. Lastly, this research is a steppingstone toward a more detailed longitudinal study of environmental justice in Illinois. 


\section{Introduction}

This study will examine the relationship that existing Superfund sites have with the surrounding area and their communities. Particular significance will be placed on the socioeconomic indicators that have been determined to be indicators of environmental injustice to include racial minority, median household income, and home ownership (Rhodes 2003; Pastor et al. 2004; Bevc et al. 2007; Bowen et al. 1995). This analysis will not focus on the original socioeconomic demographics at the time of the placement of the Superfund site; rather a current survey will be taken using Census 2000 data. Additionally, this analysis will take into account that while Illinois has an overall minority percentage of $26.5 \%$, the mean percentage of racial minorities in Illinois counties is $7.4 \%$ and as such, could affect the outcome of the analysis (U.S. Census Bureau 2000). With this in mind, the factors of median household income and home ownership were added to the analysis to balance the results.

The foundation for the paradigm of environmental justice is that communities of color and low income households disproportionately and unjustly bear the burden of environmental degradation (Rhodes 2003; Bullard 1990; Commission for Racial Justice 1987; Mohai \& Bryant 1992). The Environmental Protection Agency, or EPA, formally defines environmental justice as “...the fair treatment and meaningful involvement of all people regardless of race, color, national origin, or income with respect to the development, implementation, and enforcement of environmental laws, regulations, and policies" (U.S. EPA 2008b). "Fair treatment implies that no population of people should be forced to shoulder a disproportionate share of the negative environmental impacts of pollution or environmental hazards due to lack of political or economic strength" (Rhodes 2003). The struggle for environmental justice originated with the 1982 battle over the placement of a PCB laden landfill in North Carolina (Bullard \& Johnson 2000). This 
minority-led march, the 1979 research of Dr. Robert Bullard concerning the inequities found in the placement of landfills and incinerators in Houston, and the study by the United Church of Christ in 1987 awakened the public, as well as the federal government, to the concept of environmental injustice (Cutter 2006).

Superfund sites and their parent bill the Comprehensive Environmental Response, Compensation, and Liability Act of 1980 (CERCLA), originated in response to the environmental tragedy that transpired in Love Canal, New York in the late 1970s (U.S. EPAa). Unrestrained chemical dumping by the Hooker Chemical Company in the abandoned canal and the ensuing leakage into surrounding homes led to public awareness of the issue and the signing of CERCLA in 1980 by President Jimmy Carter (Anderton et al. 1997). However, concern for the equitable treatment and remediation of these environmental hazards was first brought to federal attention by a U.S. General Accounting Office report in 1983 concerning the siting of environmental hazardous culminating in the decade later signing of Executive Order 12898 by President Bill Clinton in 1994 (Rhodes 2003; U.S. GAO 1983). Executive Order 12898 mandated that all existing federal agencies develop policies concerning environmental justice (Rhodes 2003). This has led to a more thorough examination of Superfund site assessment, listing, and their subsequent remediation as well as the more equitable siting of future environmental hazards. At present, Illinois has forty-three Superfund sites with thirty of the sites located within one hundred miles of Chicago, see Figure 1. 


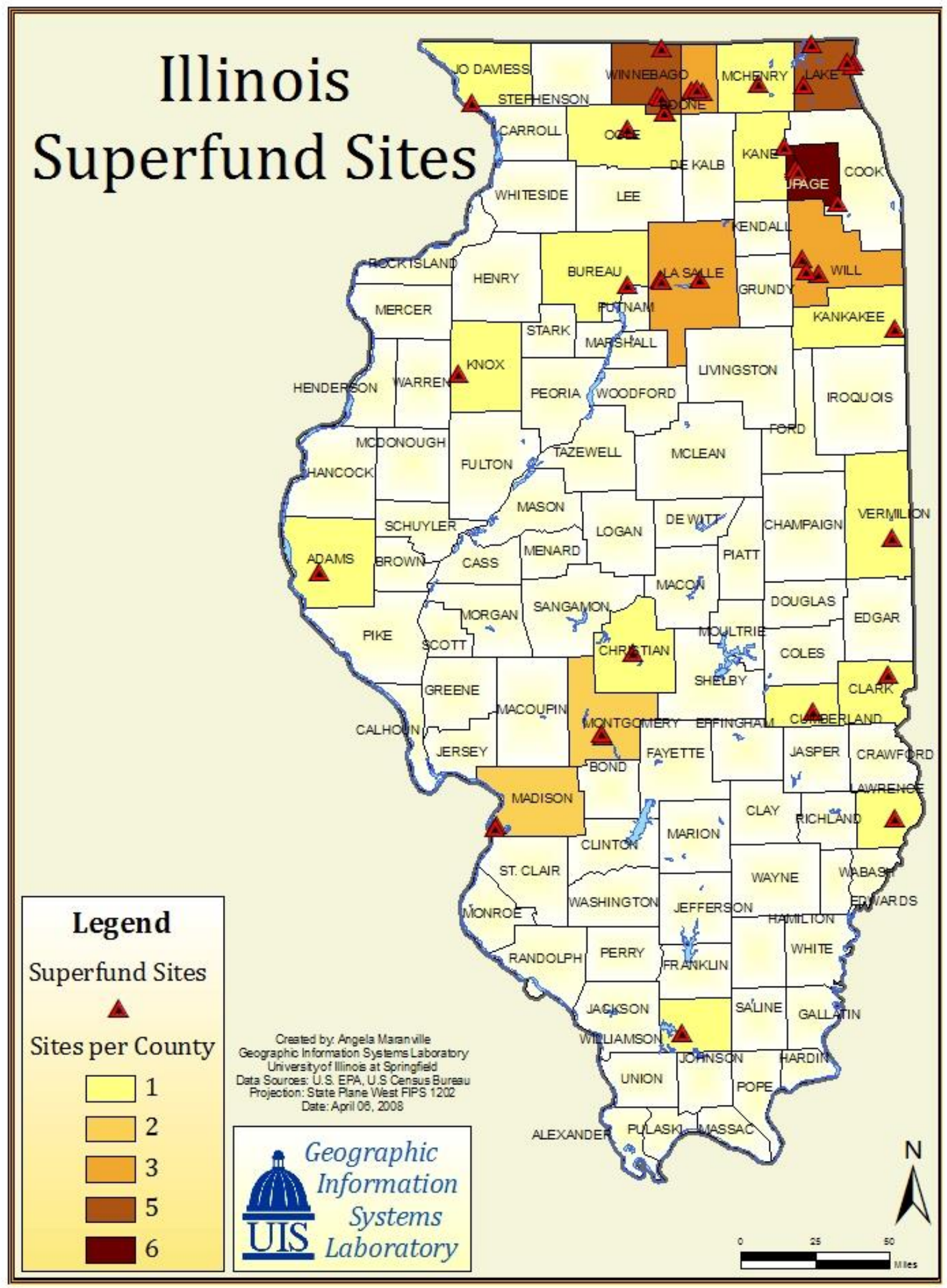

Figure 1. Illinois Superfund Sites per County 
The objective of this research is to compare within a described radius surrounding the Superfund site the percentages of racial minorities, percentage of home ownership, and average median household income to the percentage outside of the radius. As noted earlier, particular attention will be paid to the income and home ownership differences, as 76 of the 102 Illinois counties have a minority population less than $10 \%$, and only four counties, Cook, Alexander, Pulaski, and St. Clair, have percentages higher than the statewide percent of $26.5 \%$. The study hypothesis is that the existence of Superfund sites will affect the socioeconomic factors of the test areas including those counties with a small racial minority presence, once the additional factors of median household income and home ownership are examined.

\section{Methods}

The geographic area that will be studied is the state of Illinois and the 22 counties that contain the 43 Superfund sites. The counties studied are Adams, Boone, Bureau, Christian, Clark, Cumberland, DuPage, Jo Daviess, Kane, Kankakee, Knox, Lake, La Salle, Lawrence, McHenry, Madison, Montgomery, Ogle, Vermilion, Will, Williamson, and Winnebago.

Data necessary for this project includes population and home ownership data at the block group level from the 2000 U.S. Census Bureau retrieved via ESRI. Median household income data at the block group level was retrieved from The University of Wisconsin-Milwaukee Employment and Training Institute as a compilation of the 2000 U.S. Census Bureau's long form questionnaire, SF3. This questionnaire reflects only a portion of the block group as the questionnaire is only given to 1 in 6 households. The location of the 43 Illinois Superfund sites was obtained by querying the U.S. EPA's Superfund Site Information page and retrieving the latitude and longitudinal information for each site. NationalAtlas.gov was also used in the map creation providing base layers such as water and county and state boundaries. 
Areal apportionment will be used as the distance-based methodology to analyze the socioeconomic makeup of the neighborhoods that surround the 43 Superfund sites. This methodology is considered more precise than unit-hazard coincidence methods because "each unit's population is weighted by the proportion of the area of the unit captured by the circle" (Mohai and Saha 2006). Areal apportionment will provide a more accurate glimpse into the neighborhoods surrounding the Superfund sites. One vital assumption that is necessitated by areal apportionment as well as all the other distance-based methods and unit-hazard coincidence methods is that the studied neighborhood's population and the accompanying demographics are evenly distributed over the area. This assumption, while not typical of an actual neighborhood, still gives researchers the best representation of demographics within the block group at this time.

A GIS layer containing the state and county boundaries of Illinois was projected to NAD 1983 Illinois StatePlane West FIPS 1202. Then using the latitude and longitudinal data from the U.S. EPA, a Superfund sites layer was created. The U.S. Census 2000 data was also added to the map as a new database file and joined to the appropriate spatial layer. Next, a database file containing the income data was added to the map, joined to the block group data, and used to create a new socioeconomic layer for Illinois. Once these layers were in place, three separate buffer zone layers were created using the individual Superfund sites as the epicenter. Buffer zones of one-mile, two-miles, and five-miles were created specifically using no dissolving of features so the Superfund sites could be individually identified in later analysis. These radii were selected based on earlier research and in an attempt to track the changes in socioeconomic impact over distance from a studied hazard (Mohai \& Saha 2006; Pastor et al. 2004; Anderton et al. 1997; Bevc et al. 2007). Using the three new zonal layers, the census and income layers were 
intersected with the buffer zones to create three new layers. A field was added to reflect total minority, which was calculated using all categories other than white. These categories are American Indian and Alaska Native, Asian, Black or African American, Native Hawaiian and Other Pacific Islander, Hispanic, Some Other Race, and Two or More Races. Once summed, areal apportionment was applied and the total minority for each block group was multiplied by the proportional area of the corresponding partial block group, which was determined by using the XTools Pro extension to calculate the area of each partial block group and dividing by the total area of the buffer. Areal apportionment was repeated for the socioeconomic factors of population, homeowners, total housing units, and median household income. These layers were summarized by site name and the resulting database files were moved to an Excel spreadsheet for further analysis to determine minority percentages within the buffer, which are determined by dividing proportional minority by proportional population, home ownership percentages within the buffer, which are determined by dividing proportional homeowners by total housing units, and average median household income within the buffer, which is determined by averaging the proportional median household income at each site.

The resulting databases only reflect the percentages within the three buffer zones for each site so to be effective the data had to be compared to the county outside each buffer zone, as the percentages would differ for each zonal radius. This was solved by creating a reverse clip using the existing buffer zones and the erase tool in the XTools Pro extension. This created three new layers that excluded the buffer zones, but included the rest of the county's surrounding demographics. These layers were used to clip the census and income data layer creating three new layers. Again, areal apportionment was used to analyze these layers creating values for minority percentage, home ownership percentage, and average median household income for the 
remaining county outside the buffer. However, in counties that contain more than one Superfund site there is no discernible way to distinguish by site so the resulting data was summarized by county and then used to compare to the results within the buffer zones. This lack of precision is common to analysis of this sort and presents a challenge for future research (Mohai \& Saha 2006).

The resulting data were copied into an Excel spreadsheet for further analysis. This analysis consisted of dividing the resulting minority and home ownership percentages inside the buffer zone by the respective percentages calculated outside the buffer zone by county. As the buffer zone widened, the percentage difference was calculated again. This created three separate sets of percentage differences for each site within each buffer zone. The income data was treated similarly with the average median household income inside the buffer being divided by the county average outside the buffer. This resulted in a percentage that could be used for comparison purposes. The resulting percentages were ranked to determine if the sites were lower or higher than the surrounding county and if so, how far out the discrepancies continued from the site. This information was used to create graphs and cholorpleth maps that highlight the resulting discrepancies.

\section{Results}

The results of the project varied as was to be expected with such a large and diverse demographic sample as was demonstrated by the state of Illinois; however, minority, household income, and home ownership inequities were shown to exist in a majority of the affected counties particularly at the one-mile radius. The results are presented by buffer zone distance and separated into two groups. Minority results are separated from the home ownership and median 
household income results due to difficulties graphing percentages as high as $800 \%$ for minority differences and the much lower median household income and home ownership differences.

\section{One-Mile Results}

The one-mile results clearly reveal median household income discrepancies at 25 of the 43 Superfund sites located in thirteen counties to include Boone, Bureau, Cumberland, DuPage, Jo Daviess, Kankakee, La Salle, Lake, Madison, McHenry, Vermilion, Will and Winnebago with two sites in Lake County having the lowest median household income percentage. These sites are Outboard Marine Corporation with a median household income 33\% lower than the outlying county and Johns-Manville Corporation with a percentage 59.2\% lower than the surrounding county. Home ownership discrepancies were discovered at 22 of the 43 Superfund sites and located in twelve counties to include Boone, Bureau, DuPage, Kankakee, La Salle, Lake, Lawrence, Madison, McHenry, Montgomery, Will, and Winnebago with two sites located in Lake County with the lowest home ownership percentages. These sites are Outboard Marine Corporation with a home ownership percentage $36 \%$ lower than the surrounding county and Yeoman Creek Landfill with a percentage $64.3 \%$ lower than the Lake County home ownership percentage, see Figure 2.

Minority discrepancies at the one-mile radius were discovered at 24 of the 43 Superfund sites and located in thirteen counties to include Boone, Bureau, Clark, Cumberland, DuPage, Kankakee, Lake, La Salle, Lawrence, Madison, McHenry, Williamson, and Winnebago. The two sites with the highest minority discrepancies are Depue/New Jersey Zinc/Mobil Chemical Corporation site in Bureau County with a $863 \%$ higher minority percentage than the county percentage and Sangamo Electric Dump/Crab Orchard National Wildlife Refuge in Williamson County with a $433 \%$ higher minority percentage than the county percentage, see Figure 3. 


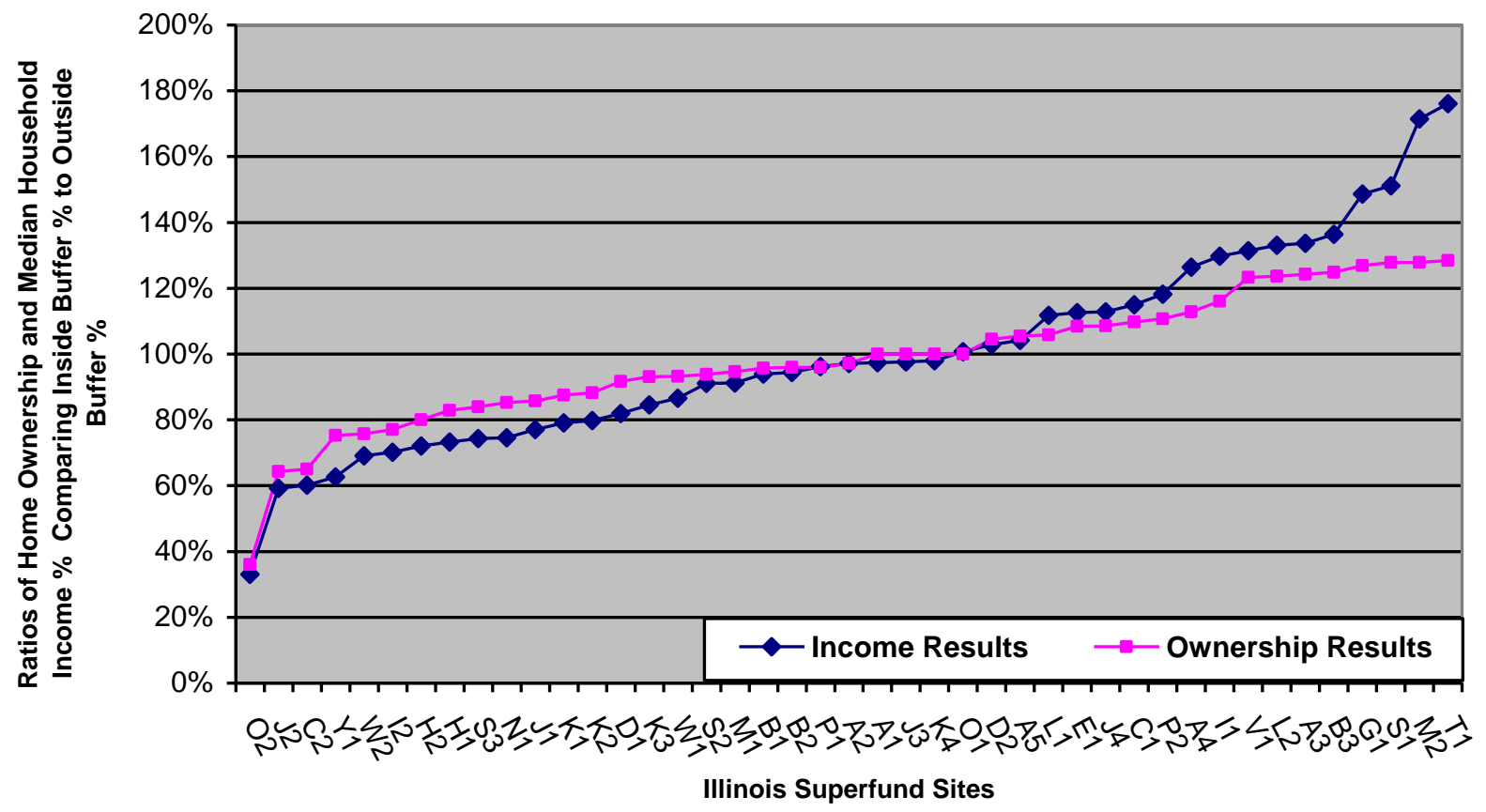

Figure 2. Home Ownership and Median Household Income Results 1-Mile

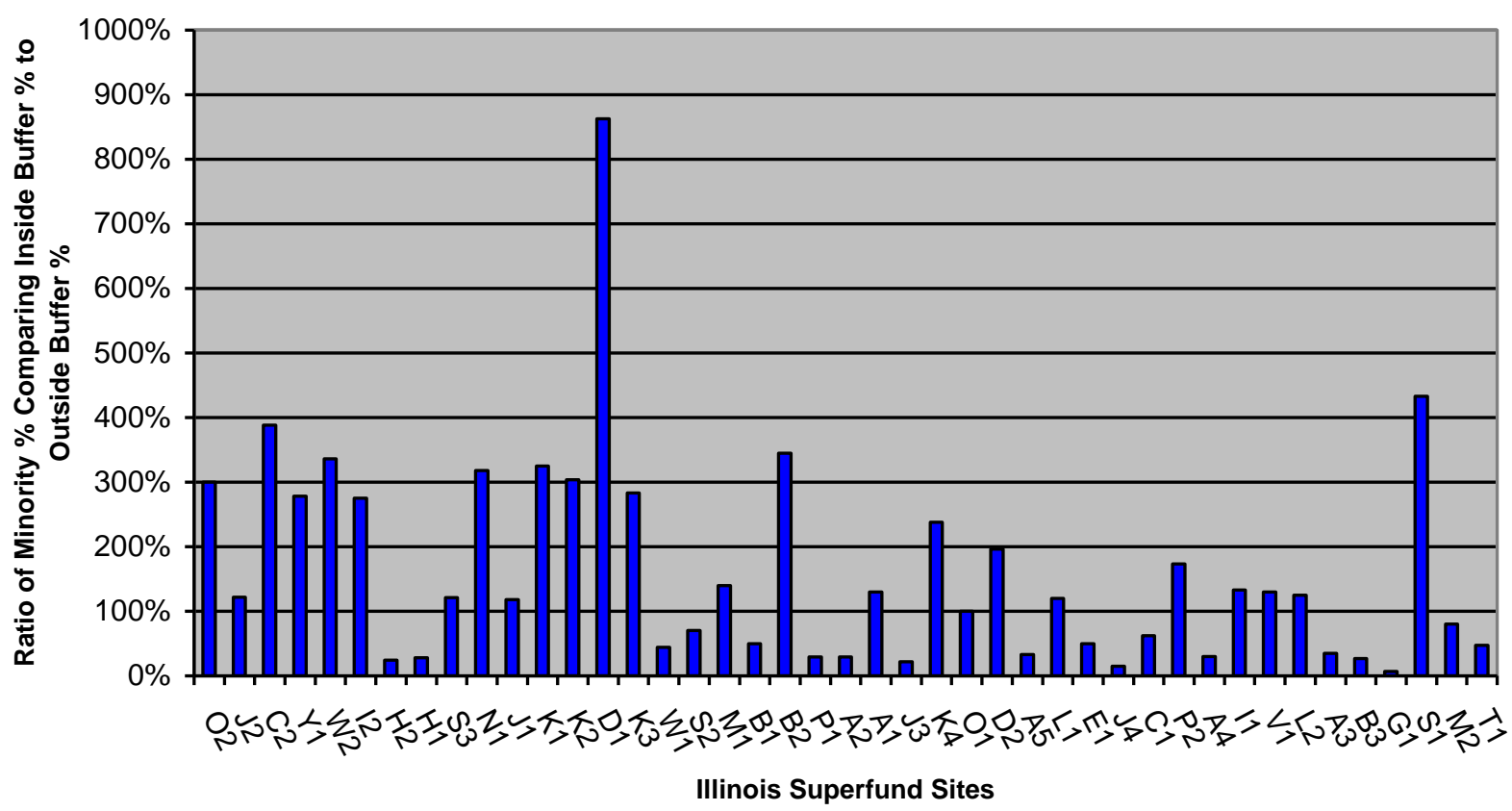

Figure 3. Minority Results 1-Mile 


\section{$\underline{\text { Two-Mile Results }}$}

The results for the two-mile analysis were equally as noteworthy. Median household income discrepancies were discovered at seventeen of the 43 Superfund sites and located in eight counties to include Bureau, DuPage, Lake, Kankakee, Madison, Winnebago, Jo Daviess, and McHenry. The lowest median household income percentages were noted in two Lake County sites with the Outboard Marine Corporation site having a median household income percentage $32.43 \%$ lower than the surrounding county and the Johns-Mansville Corporation site having a median household percentage $42.7 \%$ lower than the remainder of Lake County. Home ownership discrepancies were noted at 23 of the 43 Superfund sites. These are located in ten counties to include Boone, La Salle, Lawrence, Kankakee, Cumberland, Winnebago, DuPage, Madison, McHenry, and Lake. The lowest home ownership percentages were located at the Outboard Marine Corporation site with a home ownership rate $68.77 \%$ lower than the remainder of Lake County and in McHenry County at the Woodstock Municipal Landfill with a home ownership rate $69.33 \%$ lower than the surrounding county, see Figure 4.

Minority discrepancies for the two-mile buffer zone were discovered at 23 of the 43 Superfund sites. These are located in twelve counties to include Bureau, Williamson, Kankakee, Lake, Madison, McHenry, Winnebago, DuPage, Boone, Lawrence, Clark, and La Salle. The highest minority inequities were found in Bureau County at the DePue/New Jersey Zinc/Mobile Chemical Corporation site with a minority percentage $596.75 \%$ higher that the remainder of the county and in Williamson County the Sangamo Electric Dump/Crab Orchard National Wildlife Refuge with a minority percentage $430.30 \%$ higher than the surrounding county, see Figure 5. 

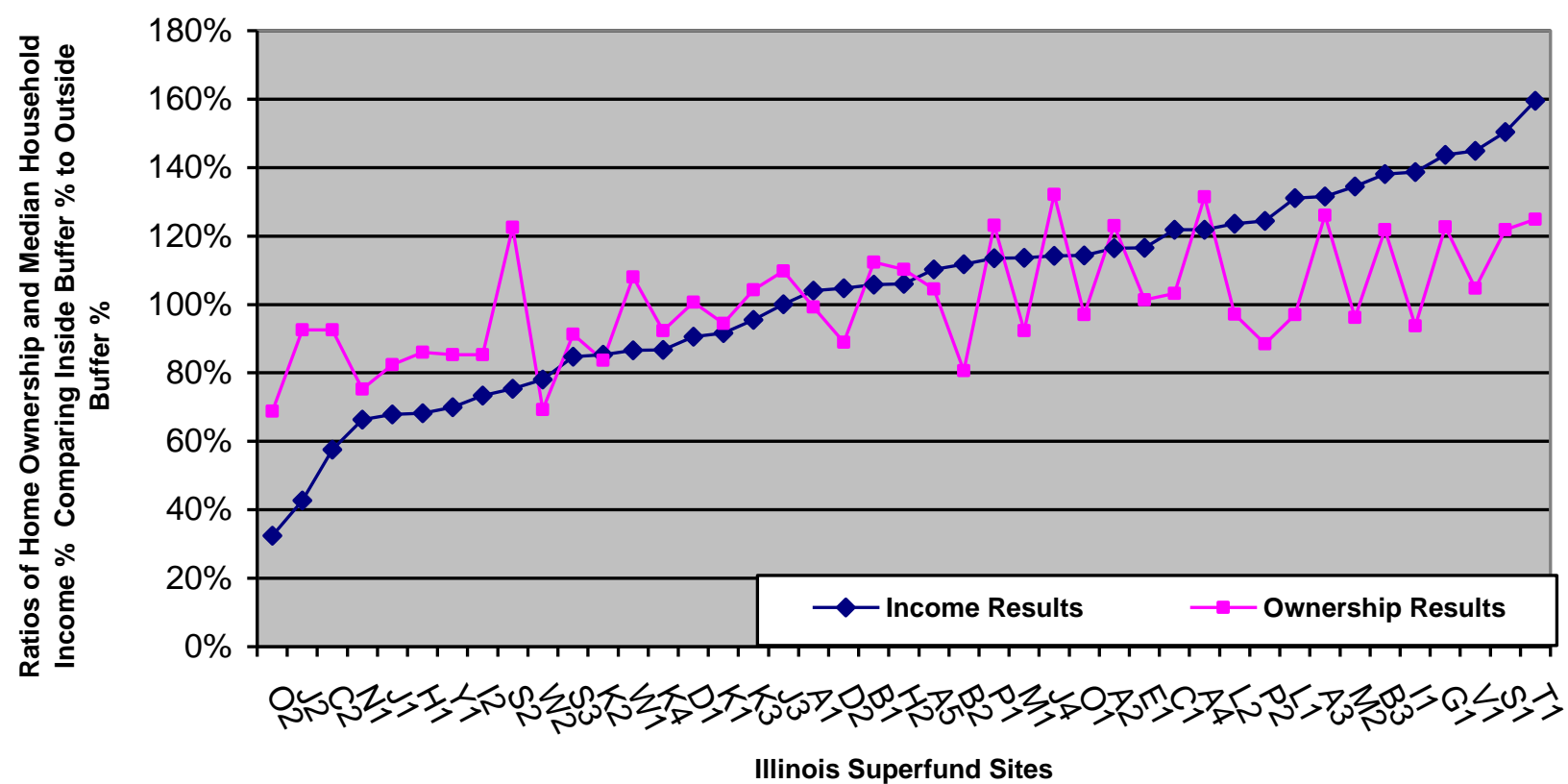

Figure 4. Home Ownership and Median Household Income Results 2-Miles

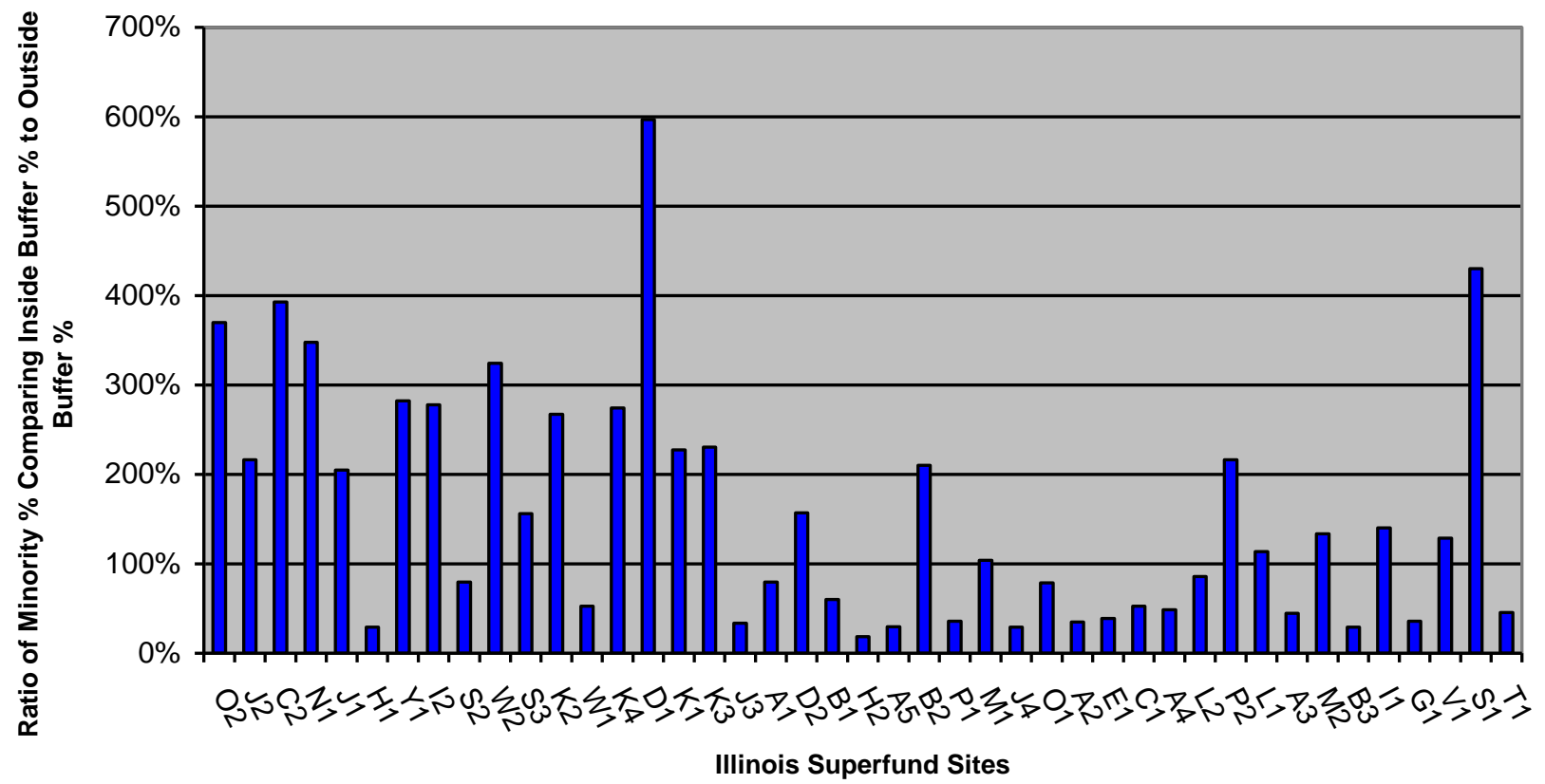

Figure 5. Minority Results 2-Miles 


\section{$\underline{\text { Five-Mile Results }}$}

Lastly, the analysis of the five-mile results also indicates median household income discrepancies at seventeen of the 43 Superfund sites. These are located in eight counties to include Bureau, DuPage, Jo Daviess, Kankakee, Lake, Madison, McHenry, and Winnebago with the lowest median household income percentages in two Lake county sites. The two sites with the worst median household income ratios are Outboard Marine Corporation at $31.43 \%$ of the county average and the Johns-Manville Corporation site with $33.62 \%$ of the remaining county average. Home ownership discrepancies were also noted at the five-mile radius at 21 of the 43 Superfund sites. These are located in eleven counties to include Lake, Madison, Kankakee, Winnebago, DuPage, Bureau, Jo Daviess, La Salle, Lawrence, McHenry, and Will. The site with the lowest home ownership ratio is Jennison-Wright Corporation with $77 \%$ of the home ownership average in Madison County and the second lowest site is Outboard Marine Corporation with a home ownership percentage $78 \%$ of the average in Lake County, see Figure 6.

Minority results at the five-mile radius indicated discrepancies as well. Discrepancies were found at 22 of the 43 sites. These are located in twelve counties to include Bureau, Knox, Williamson, Kankakee, Clark, Lawrence, Madison, Boone, DuPage, Winnebago, Lake, and McHenry. The site with the highest minority ratio is again the DePue/New Jersey Zinc/Mobil Chemical Corporation site in Bureau County with $444.06 \%$ higher than the county minority percent and the second highest minority percentage is found in Williamson County at the Sangamo Electric Dump/Crab Orchard National Wildlife Refuge with $405.84 \%$ higher than the county percentage, see Figure 7. 


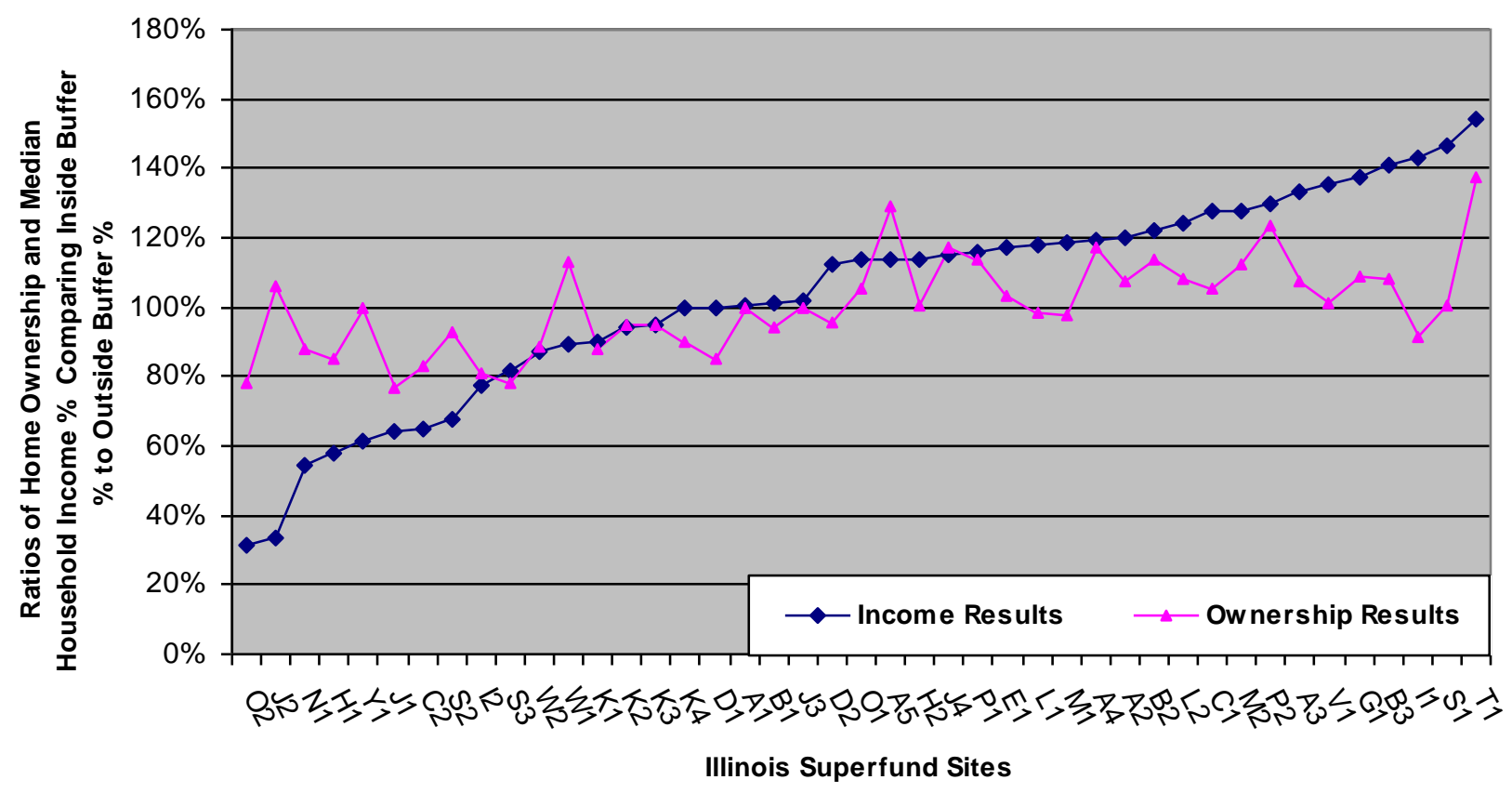

Figure 6. Home Ownership and Median Household Income Results 5-Miles

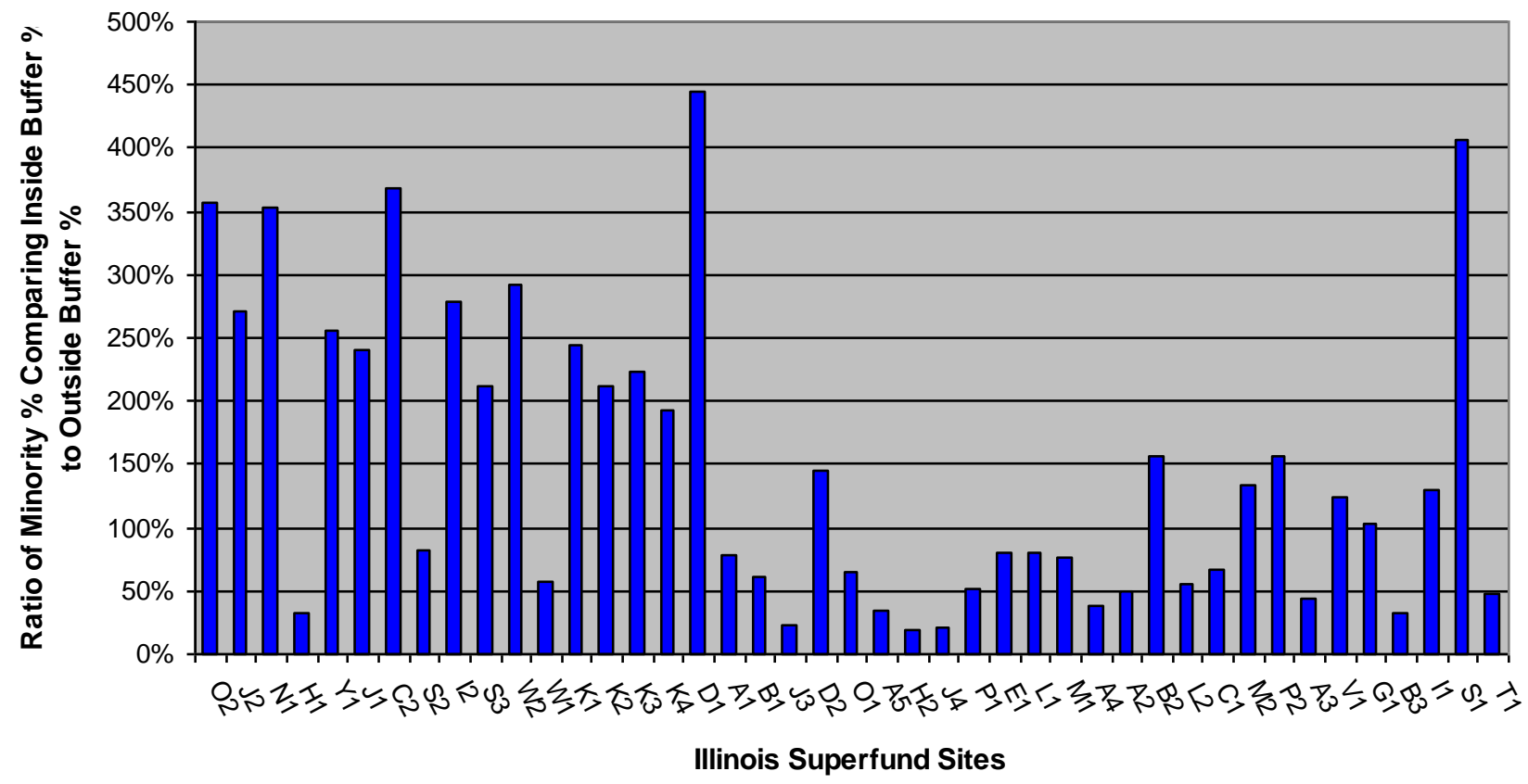

Figure 7. Minority Results 5-Miles 
When all three socioeconomic criteria are considered, fifteen sites meet all three indicators of higher minority, lower median household income, and lower home ownership ratios at the one-mile radius. These sites are located in Boone, Bureau, DuPage, Kankakee, La Salle, Lake, Madison, McHenry, and Winnebago Counties, see Table 1. Twelve sites meet all three criteria at the two-mile radius in Lake, Kankakee, Madison, Winnebago, McHenry, and DuPage Counties, see Table 2. Thirteen sites meet all three criteria at the five-mile radius in Lake, Madison, Winnebago, Kankakee, McHenry, DuPage, and Bureau Counties, see Table 3. Of these sites, ten meet the criteria for higher minority, lower median household income, and lower home ownership within all three radii. These sites are NL Industries/Taracorp Lead Smelter and Jennison-Wright Corporation in Madison County, Outboard Marine Corporation and Yeoman Creek Landfill in Lake County, Kerr-McGee Reed-Keppler Park and Kerr-McGee (Kress Creek/West Branch of DuPage River) in DuPage County, Cross Brothers Pail Recycling in Kankakee County, Interstate Pollution Control, Inc. and Southeast Rockford Ground Water Contamination in Winnebago County, and Woodstock Municipal Landfill in McHenry County. Identification of these impacted neighborhoods can be of salient value to city and county planners. Although individual Superfund sites have not been expressly identified as the cause of the environmental injustices discovered by this research, planners can utilize this knowledge to identify more equitable placement for future environmental hazards. Additionally, policies can be implemented to ameliorate the affected neighborhoods, cities, and counties returning them to viable, thriving neighborhoods unaffected by the blight of the nearby toxic site (Pastor et al. 2005). 
Table 1. Superfund Sites That Meet Criteria for Minority, Median Household Income, and Home Ownership At One Mile.

\begin{tabular}{|c|c|c|c|c|}
\hline Site Name & County & Income & Minority & Ownership \\
\hline Outboard Marine Corporation & Lake & $33.0 \%$ & $300 \%$ & $36.0 \%$ \\
\hline Johns-IVlanville Corporation & Lake & $59.2 \%$ & $122 \%$ & $64.3 \%$ \\
\hline Cross Bros. Pall Recycling & Kankakee & $60.2 \%$ & $388 \%$ & $65.0 \%$ \\
\hline Yeoman Creek Landfill & Lake & $62.7 \%$ & $278 \%$ & $75.3 \%$ \\
\hline Woodstock Municipal Landfill & McHenry & $69.1 \%$ & $336 \%$ & $75.7 \%$ \\
\hline Interstate Pollution Control, Inc. & Winnebago & $70.2 \%$ & $275 \%$ & $77.0 \%$ \\
\hline Southeast Rockford Ground Water Contamination & Winnebago & $74.3 \%$ & $121 \%$ & $84.0 \%$ \\
\hline NL Industries/laracorp Lead Smelter & Madison & $74.5 \%$ & $318 \%$ & $85.3 \%$ \\
\hline Jennison-Wright Corporation & Madison & $77.0 \%$ & $118 \%$ & $85.7 \%$ \\
\hline Kerr-McGee (Kress Creek/ West Branch of Dupage River & DuPage & $79.1 \%$ & $325 \%$ & $87.5 \%$ \\
\hline Kerr-IVICGee Reed-Keppler Park & DuPage & $79.8 \%$ & $304 \%$ & $88.2 \%$ \\
\hline DePue/New Jersey Zinc/Mobil Chemical Corp & Bureau & $81.9 \%$ & $863 \%$ & $91.7 \%$ \\
\hline Kerr-McGee Residential Areas & DuPage & $84.6 \%$ & $283 \%$ & $93.1 \%$ \\
\hline Matthiessen and Hegeler Zinc Co. & La Salle & $91.2 \%$ & $140 \%$ & $94.7 \%$ \\
\hline Belvidere Municipal Landfill & Boone & $94.4 \%$ & $345 \%$ & $95.9 \%$ \\
\hline
\end{tabular}

Table 2. Superfund Sites That Meet Criteria for Minority, Median Household Income, and Home Ownership at Two Miles.

\begin{tabular}{|c|c|c|c|c|}
\hline Site Name & County & Income & Minority & Ownership \\
\hline Outboard Marıne Corporation & Lake & $32.4 \%$ & $369.8 \%$ & $68.8 \%$ \\
\hline Johns-Manville Corporation & Lake & $42.7 \%$ & $216.5 \%$ & $92.6 \%$ \\
\hline Cross Bros. Pall Recycling & Kankakee & $57.5 \%$ & $392.7 \%$ & $92.5 \%$ \\
\hline NL Industries/l aracorp Lead Smelter & Madison & $66.3 \%$ & $347.8 \%$ & $75.2 \%$ \\
\hline Jennison-Wright Corporation & Madison & $67.9 \%$ & $204.9 \%$ & $82.4 \%$ \\
\hline Yeoman Creek Landfill & Lake & $70.0 \%$ & $282.4 \%$ & $85.3 \%$ \\
\hline Interstate Pollution control, Inc. & Winnebago & $73.4 \%$ & $278.1 \%$ & $85.4 \%$ \\
\hline Woodstock Municipal Landfill & McHenry & $78.0 \%$ & $324.2 \%$ & $69.3 \%$ \\
\hline Southeast Rockford Ground Water Contamination & Winnebago & $84.7 \%$ & $156.1 \%$ & $91.3 \%$ \\
\hline Kerr-McGee Reed-Keppler Park & DuPage & $85.3 \%$ & $267.2 \%$ & $83.7 \%$ \\
\hline Kerr-McGee Sewage Treatment Plant & DuPage & $86.8 \%$ & $274.5 \%$ & $92.3 \%$ \\
\hline Kerr-IVICGee (Kress Creek/Wvest Branch of Dupage RIver & DuPage & $91.7 \%$ & $227.2 \%$ & $94.5 \%$ \\
\hline
\end{tabular}

Table 3. Superfund Sites That Meet Criteria for Minority, Median Household Income, and Home Ownership at Five Miles.

\begin{tabular}{|c|c|c|c|c|}
\hline Site Name & County & Income & Minority & Ownership \\
\hline Outboara milarine Corp. & Lake & $31.4 \%$ & $356.4 \%$ & $78.0 \%$ \\
\hline INL Inaustries/Taracorp Lead smelter & Madison & $54.8 \%$ & $352.4 \%$ & $88.0 \%$ \\
\hline Yeoman Creek LandillI & Lake & $61.2 \%$ & $255.6 \%$ & $99.5 \%$ \\
\hline Jennison-VVright corporation & Madison & $64.5 \%$ & $240.5 \%$ & $77.0 \%$ \\
\hline Cross Bros. Pall Recycing & Kankakee & $64.9 \%$ & $368.8 \%$ & $83.3 \%$ \\
\hline Interstate Pollution Control, Inc. & Winnebago & $77.7 \%$ & $279.0 \%$ & $80.9 \%$ \\
\hline southeast Rockiora Ground vater Contamination & Winnebago & $81.8 \%$ & $212.0 \%$ & $78.3 \%$ \\
\hline VVoodstock TVIUnicipal LanaillII & McHenry & $87.4 \%$ & $291.3 \%$ & $88.8 \%$ \\
\hline Kerr-IVICGee (Kress Creek/vvest Branch ol Dupage River & DuPage & $89.8 \%$ & $243.8 \%$ & $87.6 \%$ \\
\hline Kerr-IVICGee Reed-Keppler Park & DuPage & $94.1 \%$ & $212.1 \%$ & $95.2 \%$ \\
\hline Kerr-McGee Residential Areas & DuPage & $94.6 \%$ & $223.1 \%$ & $94.9 \%$ \\
\hline Kerr-McGee Sewage Treatment Plant & DuPage & $99.6 \%$ & $192.6 \%$ & $89.8 \%$ \\
\hline DePue/New Jersey Zinc/Mobil Chemical Corp & Bureau & $99.9 \%$ & $444.1 \%$ & $85.4 \%$ \\
\hline
\end{tabular}


In addition, when individual socioeconomic factors are compiled, the resulting graphs indicate that typically, as you move further from the hazard the disparities decrease, see Figures 8,9 , and 10. A specific example of median household income increasing as you move away from the Superfund site is the Interstate Pollution Control site with ratios beginning at $70.2 \%$, moving to $73.43 \%$ at two-miles, and raising to $77.65 \%$ at five-miles. An example from the minority analysis is the DePue/New Jersey Zinc/Mobil Chemical Corporation site beginning at $863 \%$ at one-mile, lowering to $596.75 \%$ at two-miles, and to $444.06 \%$ at five-miles. The home ownership results have the least amount of variance, however, the Kerr-McGee Reed-Keppler Park site shows an increasing home ownership ratio as you move away from the site beginning with $36 \%$ at one-mile, raising to $83.7 \%$ at two-miles, and to $95.2 \%$ at five-miles.

Statistical analysis using an independent samples t-test was conducted to verify if there were significant differences between the ratios of each socioeconomic criterion at each distance inside the buffer and outside the buffer. Only the minority percentages showed significant differences and then only at one-mile $(t=2.053, \mathrm{df}=84, \mathrm{P}<.05)$ and two-miles $(t=2.139, \mathrm{df}=84$, $\mathrm{P}<.05)$. In addition, a Pearson's product moment correlation analysis was conducted to explore the relationship between the socioeconomic factors of median household income, home ownership, and minority ratio. A highly significant negative relationship exists between median household income and minority ratio $(r=-.484, \mathrm{df}=42, \mathrm{P}<.01)$ and between minority ratio and home ownership $(r=-.578, \mathrm{df}=42, \mathrm{P}<.01)$. A highly significant positive relationship exists between median household income and home ownership $(r=.616, \mathrm{df}=42, \mathrm{P}<.01)$. These significant relationships validate the addition of median household income and home ownership to environmental justice research. 


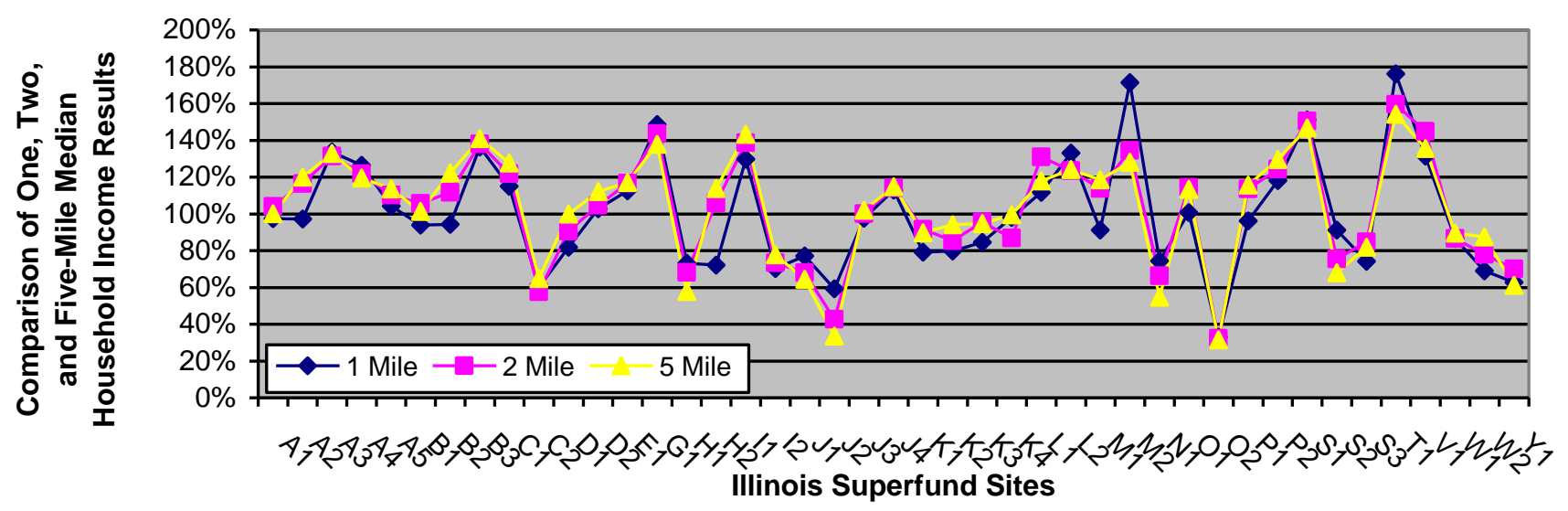

Figure 8. Median Household Income Results for Illinois Superfund Sites

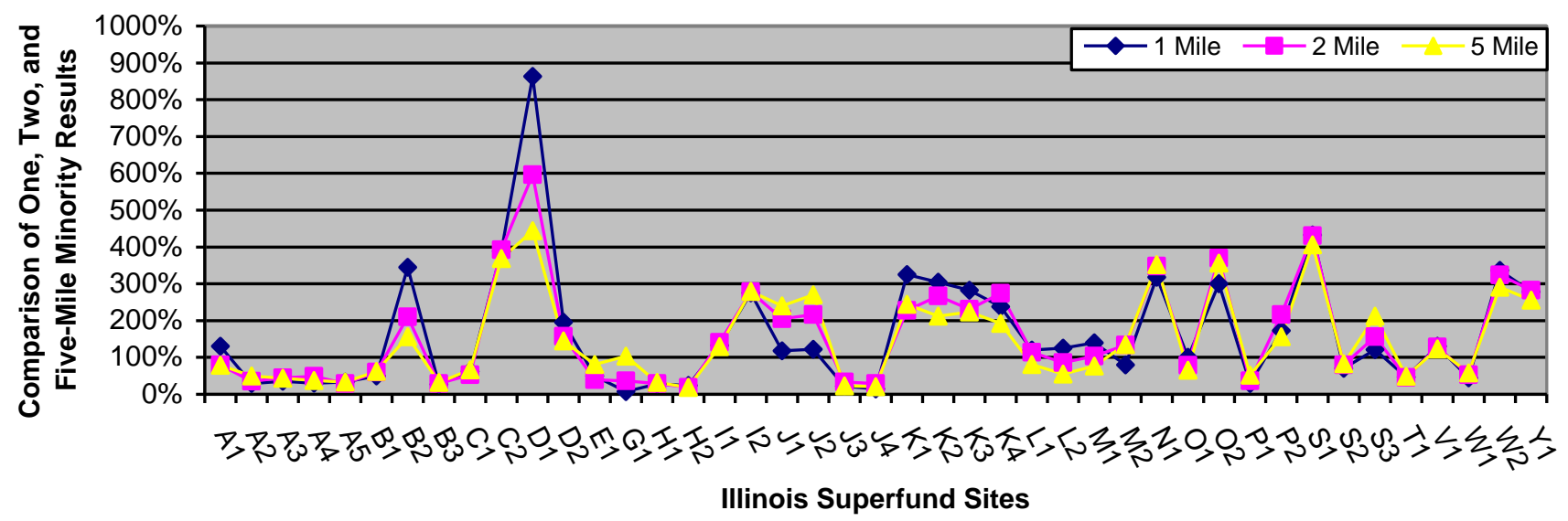

Figure 9. Minority Results for Illinois Superfund Sites

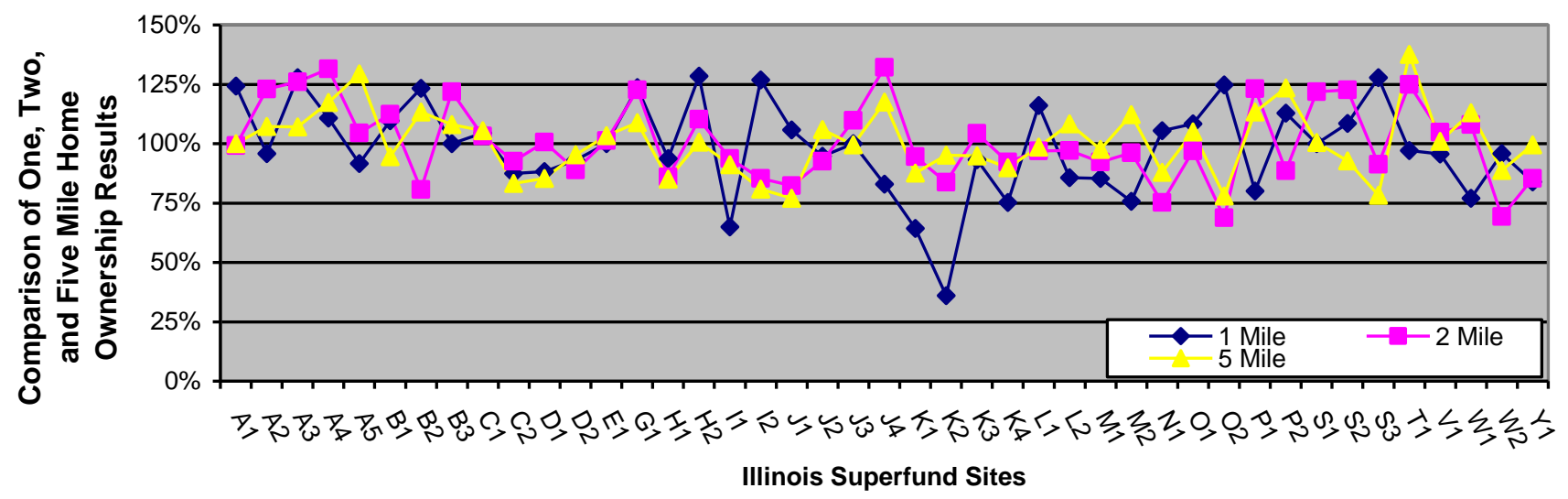

Figure 10. Home Ownership Results for Illinois Superfund Sites 


\section{Conclusion}

The primary results of this project indicate that environmental injustice demographic markers are found in Illinois. As recently as 2000, conditions were being met in Illinois for environmental injustices within the one-mile, two-mile, and five-mile radii. This implied vulnerability to injustices can be further complicated by the continued placement of new Toxic Release Inventory sites (TRI's), landfills, or other environmental hazards. Secondly, of the 22 counties that contain Superfund sites, fourteen have minority percentages lower than $10 \%$ and of these fourteen, seven display environmental inequities that would not be apparent in a minority only analysis. This validates the premise that socioeconomic factors of median household income and home ownership are impacted by proximity to an environmental hazard and as such can be a valuable addition to environmental justice research. Ironically, the two sites that exhibit the greatest minority discrepancies are in Bureau and Williamson Counties, which have minority percentages of $3.2 \%$ and $4.7 \%$ respectively.

This analysis, unlike other GIS based research, uses inclusive buffer zones rather than annular buffer zones that would individualize the socioeconomic demographics from the epicenter to the one-mile radius, the one-mile to the two-mile radius, and the two-mile to the five-mile radius. Use of the inclusive buffer could obscure some of the specific data pertaining to the change in socioeconomic demographics over distance. Further research will implement this form of annular buffer analysis for added precision. In addition, the challenge of separating the data by site in counties with more than one Superfund site will be addressed in the future to again increase the accuracy of the research. Furthermore, supplementary research is required to track the past, present, and ongoing placement of environmental hazards in conjunction with these counties in Illinois. Alternatively, a qualitative study of the populace within the affected 
neighborhoods could increase our understanding as planners and researchers of a community's response to living adjacent to an environmental hazard. Lastly, a longitudinal study of affected Illinois counties, to include mapping of the placement of other environmental hazards, would institute a significant step toward a fuller understanding of environmental injustice in Illinois. 


\section{References}

Anderton, D., Oakes, J., \& Egan, K. 1997. "Environmental Equity in Superfund: Demographics of the Discovery and Prioritization of Abandoned Toxic Sites.” Evaluation Review, 21(1), 3-26.

Bevc, C., Marshall, B., \& Picou, J. 2007. "Environmental justice and toxic exposure: Toward a spatial model of physical health and psychological well-being." Social Science Research, $36,48-67$.

Bowen, W., Salling, M., Kingsley, H., \& Cyran, E. 1995. “Toward Environmental Justice: Spatial Equity in Ohio and Cleveland." Annals of the Association of American Geographers, 85(4), 641-663.

Bullard, Robert D. 1990. Dumping in Dixie: Race, Class, and Environmental Quality. Boulder, Colo.: Westview Press.

Bullard, Robert H., and Glenn S. Johnson. 2000. Environmental Justice: Grassroots Activism and Its Impact on Public Policy Decision Making. Journal of Social Issues 56(3), 555-578.

Commission for Racial Justice (CRJ). 1987. Toxic Waste and Race in the United States: A National Report on the Racial and Socioeconomic Characteristics of Communities With Hazardous Waste Sites. New York: United Church of Christ.

Cutter, Susan L. 2006. Hazards, Vulnerability, and Environmental Justice. London: Earthscan.

Mohai, P. \& Bryant, B. 1992. "Environmental Racism: Reviewing the Evidence.” Pp. 163-176 in Bunyan Bryant and Paul Mohai, eds., Race and the Incidence of the Environmental Hazards: A Time for Discourse. Boulder, Colo.: Westview Press.

Mohai, P. \& Saha, R. 2006. "Reassessing Racial and Socioeconomic Disparities in Environmental Justice Research.” Demography, 43.2, 383-399. 
NationalAtlas GIS Layers. 2008. Map layers. January 12, 2008. 〈http://www.nationalatlas.gov〉.

Pastor, M. Jr., Morello-Frosch, R., \& Sadd, J. 2005. “The Air Is Always Cleaner on the Other Side: Race, Space, and Ambient Air Toxics Exposures in California”. Journal of Urban Affairs, 75(2), 127-148.

Pastor, M. Jr., Sadd, J., \& Morello-Frosch, R. 2004. "Waiting to Inhale: The Demographics of Toxic Air Release Facilities in 21st-Century California.” Social Science Quarterly, 85(2), 420-440.

Rhodes, Edwardo L. 2003. Environmental Justice in America: A New Paradigm. Bloomington, IN: Indiana University Press.

University of Wisconsin at Milwaukee. 2008. Shapefiles and Databases for the U.S. January 10, 2008. <http://www.uwm.edu/Dept/ETI/PurchasingPower/ETIshapefiles.htm>.

U.S. Census Bureau 2000 Demographics. 2008. Census 2000 TIGER/ Line Data. January 10, 2008. 〈http://www.esri.com>.

U.S. Environmental Protection Agency. 2008a. CERCLIS Database. January 10, 2008. <http://cfpub.epa.gov/supercpad/cursites/srchsites.cfm>.

U.S. Environmental Protection Agency. 2008b. Environmental Justice. January 10, 2008. <http://www.epa.gov/compliance/ environmentaljustice/index.html>.

U.S. General Accounting Office. 1983. Siting of Hazardous Waste Facilities and Their Correlation with Racial and Economics Status of Surrounding Communities. General Accounting Office, Washington, DC. 
Appendix: Coding for Illinois Superfund Sites

A1. A \& F MATERIAL RECLAIMING, INC.

A2. ACME SOLVENT RECLAIMING, INC. (MORRISTOWN PLANT)

A3. ADAMS COUNTY QUINCY LANDFILLS 2\&3

A4. AMOCO CHEMICALS (JOLIET LANDFILL)

A5. ASARCO TAYLOR SPRINGS

B1. BELOIT CORPORATION

B2. BELVIDERE MUNICIPAL LANDFILL

B3. BYRON SALVAGE YARD

C1. CENTRAL ILLINOIS PUBLIC SERVICE CO.

C2. CROSS BROTHERS PAIL RECYCLING (PEMBROKE)

D1. DEPUE/NEW JERSY ZINC/MOBIL CHEMICAL CORP.

D2. DUPAGE COUNTY LANDFILL/BLACKWELL FOREST PRESERVE

E1. EAGLE ZINC CO DIV OF T L DIAMOND

G1. GALESBURG/KOPPERS CO.

H1. H.O.D. LANDFILL

H2. HEGELER ZINC

I1. INDIAN REFINERY-TEXACO LAWRENCEVILLE

I2. INTERSTATE POLLUTION CONTROL, INC.

J1. JENNISON-WRIGHT CORPORATION

J2. JOHNS-MANVILLE CORP.

J3. JOLIET ARMY AMMUNITION PLANT (LOAD-ASSEMBLY-PACKING AREA)

J4. JOLIET ARMY AMMUNITION PLANT (MANUFACTURING AREA)

K1. KERR-MCGEE (KRESS CREEK/WEST BRANCH OF DUPAGE RIVER)

K2. KERR-MCGEE (REED-KEPPLER PARK)

K3. KERR-MCGEE (RESIDENTIAL AREAS)

K4. KERR-MCGEE (SEWAGE TREATMENT PLANT)

L1. LASALLE ELECTRIC UTILITIES

L2. LENZ OIL SERVICE, INC.

M1. MATTHIESSEN AND HEGELER ZINC COMPANY

M2. MIG/DEWANE LANDFILL

N1. NL INDUSTRIES/TARACORP LEAD SMELTER

O1. OTTAWA RADIATION AREAS

O2. OUTBOARD MARINE CORP.

P1. PAGEL'S PIT

P2. PARSONS CASKET HARDWARE CO.

S1. SANGAMO ELECTRIC DUMP/CRAB ORCHARD NATIONAL WILDLIFE REFUGE (USDOI)

S2. SAVANNA ARMY DEPOT ACTIVITY

S3. SOUTHEAST ROCKFORD GROUND WATER CONTAMINATION

T1. TRI-COUNTY LANDFILL CO./WASTE MANAGEMENT OF ILLINOIS, INC.

V1. VELSICOL CHEMICAL CORP. (MARSHALL PLANT)

W1. WAUCONDA SAND \& GRAVEL

W2. WOODSTOCK MUNICIPAL LANDFILL

Y1. YEOMAN CREEK LANDFILL 